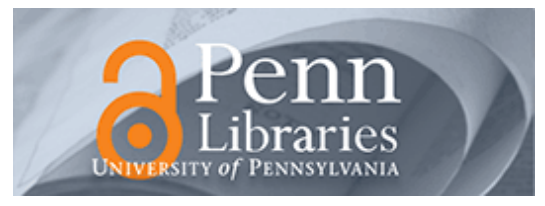

University of Pennsylvania Working Papers in Linguistics

Volume 19

Issue 2 Selected Papers from NWAV 41

Article 20

$10-17-2013$

\title{
Sociolinguistic Correlates of Negative Evaluation: Variable Concord in Rio de Janeiro
}

\author{
Maria Marta Pereira Scherre \\ Universidade Federal do Espírito Santo
}

Anthony J. Naro

anaro@gmx.net

Follow this and additional works at: https://repository.upenn.edu/pwpl

\section{Recommended Citation}

Pereira Scherre, Maria Marta and Naro, Anthony J. (2013) "Sociolinguistic Correlates of Negative Evaluation: Variable Concord in Rio de Janeiro," University of Pennsylvania Working Papers in Linguistics: Vol. 19 : Iss. 2 , Article 20.

Available at: https://repository.upenn.edu/pwpl/vol19/iss2/20

This paper is posted at ScholarlyCommons. https://repository.upenn.edu/pwpl/vol19/iss2/20

For more information, please contact repository@pobox.upenn.edu. 


\title{
Sociolinguistic Correlates of Negative Evaluation: Variable Concord in Rio de Janeiro
}

\begin{abstract}
Variable agreement in Brazilian Portuguese is subject to social stigma, under strongly negative evaluation, brought to the public's attention in 2011 in a heated nation-wide sociolinguistic debate triggered by TV Globo, the principal national television network. In order to isolate objective factors underlying this debate, we examine the variable 'years of schooling' in a trend study of Rio de Janeiro speech from 1980 and 2000. Analysis of relative weights and their corresponding ranges reveals that distance between effects of each level of education has increased over time. Polarization of the education variable in 1980 was moderate, while in 2000 polarization becomes extreme in an increasingly uneven social distribution of marked forms. The results reveal massive exacerbation of sociolinguistic apartheid, showing that nothing has changed in human interaction with respect to language despite many years of language studies. For this reason, we suggest that our sociolinguistic studies ought to trigger legal action, with creation of laws against linguistic prejudice, modeled on laws against other forms of prejudice, so that society can profit from results of sociolinguistic research in a humanistic and emancipatory way.
\end{abstract}




\title{
Sociolinguistic Correlates of Negative Evaluation: Variable Concord in Rio de Janeiro
}

\author{
Maria Marta Pereira Scherre and Anthony Julius Naro*
}

\section{Introduction}

Our main aim in this paper is to present objective sociolinguistic correlates to subjective commonsense negative evaluation and draw real-life conclusions. Specifically, we draw conclusions from the extreme polarization of VARBRUL relative weights associated with 'years of schooling' in a trend study of Rio de Janeiro speech from 1980 and 2000. Since many years of language studies show that nothing has changed in human interaction with respect to language, we suggest that our sociolinguistic studies ought to trigger legal action, with creation of laws against linguistic prejudice, modeled on laws against other forms of prejudice with respect to sexual orientation, ethnicity, gender, religion, poverty, and lower class professions.

\section{Overview of Negative Subjective Evaluation}

In 2011 a number of urban intellectuals in the Brazilian speech community got involved in a heated nation-wide sociolinguistic debate triggered by TV Globo, the principal national television network, on Jornal Nacional, its main nightly news program. This prestigious broadcast has a wide audience and is directed toward a diversified adult audience. The starting point of this resounding clash was a textbook, intended for the Education of Youth and Adults program and approved by the Ministry of Education and Culture, that mentioned three constructions without number concord, or with variable concord, and classified them as natural (Ramos 2011:14-16) in the socalled norma popular 'vernacular norm'. The standard forms of the constructions cited in the textbook, with standard plural forms and explicit plural marking shown in red, are given in (1), (2) e (3) below, while the corresponding nonstandard forms cited in the textbook are in (1a), (2a) and (3c), with words lacking explicit marking in blue.

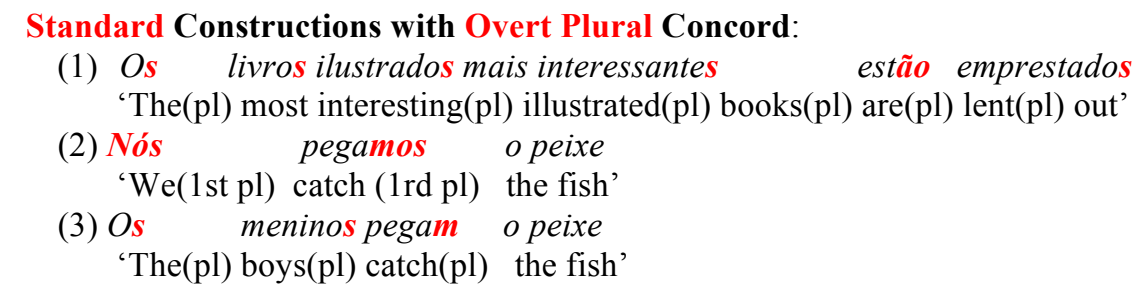

\section{Nonstandard Constructions Cited in the Textbook}

(1a) Os livro ilustrado mais interessante estão emprestado

'The(pl) most interesting(sg) illustrated(sg) book(sg) are(pl) lent(sg) out'

(2b) Nós pega opeixe

'We(1st pl) catches(3rd sg) the fish'

(3c) Os menino pega opeixe

'The(pl) boy(sg) catches(3rd sg) the fish'

Lack of overt plural agreement in Brazilian Portuguese is subject to social stigma, under strongly negative evaluation, and is generally considered a sign of "not knowing how to speak Portuguese" (see Bortoni-Ricardo et al. 2011, presented at NWAV40, as well as Bagno 2011).

\footnotetext{
* The research reported in this article is supported, in part, by grants to the authors from the Brazilian National Research Council (CNPq - Conselho Nacional de Desenvolvimento Científico e Tecnológico). 
For this reason, many people who participated in the debate, and even some linguists, were of the opinion that the inclusion of such examples was not appropriate for a textbook. Nonetheless it should be borne in mind that the objective of this particular chapter of the book, intended for young people and adults with little or no schooling, is to talk about the differences between speech and writing. One of the most salient differences in this regard is the categorical use in standard writing of explicit agreement marking, as in other Romance languages. The students tend to use less concord in their speech, although it is usually present to a certain extent.

As noted in Naro and Scherre (2013), examples of prejudiced opinions posted on the internet at the time are: Cartilha aprovada pelo MEC ensina português errado para crianças, para "incluir" os ignorantes 1 "Primer approved by the Department of Education teaches wrong Portuguese to children in order to "include" the ignorant" or Livro usado pelo MEC ensina aluno a falar errado 2 'book used by the Ministry of Education and Culture teaches students to speak wrong."

\section{Linguistic Analysis of the Three Examples in the Text Book}

Let us examine in some detail the constructions considered natural in the chapter entitled Escrever é diferente de falar 'Writing is different from speaking' in the textbook Por uma vida melhor 'Towards a better life' (Ramos 2011).

In the example (1a) (Os livro ilustrado mais interessante estão emprestado 'the(pl) most interesting(sg) illustrated(sg) book(sg) are(pl) lent(sg) out'), Ramos (2011) cites a construction with partial agreement. In subject position, there is a noun phrase explicitly marked for plural only in its left-most constituent, the definite article os 'the(pl)'. The remaining nominal elements (livro ilustrado interessante 'interesting(sg) illustrated(sg) book(sg)') have no explicit plural mark and are all low saliency on the singular/plural opposition hierarchy. The verb phrase, for its part, is in the high saliency plural form estão 'are' (although the most common realization in spoken language is tão, without the initial syllable). The low saliency predicate emprestado 'lent(sg)' also has no explicit plural mark. This is indeed a very natural structure in Brazilian Portuguese, even in the speech of educated people. Nonetheless, the cultured norm would require the fully marked form os livros ilustrados mais interessantes estão emprestados 'the( $\mathrm{pl})$ most interesting(pl) illustrated(pl) book(pl) are(pl) lent(pl) out'.

In example (2a) (nós pega o peixe 'we(1st pl) catches(3rd sg) the fish'), Ramos (2011) notes a case of a first person plural subject nós 'we' in a structure without agreement. This is also a very natural occurrence in popular speech, especially in rural or so-called rurban areas (BortoniRicardo 1985). Naro et al. (1999) present evidence that in rurban speech in Rio de Janeiro the standard form nós pegamos o peixe 'we catch or caught the fish' tends to be avoided in present tense environments. They recall that in Brazil the present and the preterit tenses are neutralized in the first person plural for regular verbs in all three conjugations.

In example (3a), Ramos (2011) notes another construction without agreement (os menino pega o peixe 'the( $\mathrm{pl})$ boys(sg) catch(sg) the fish'). This is beyond a shadow of a doubt a very natural structure in the speech of most speakers of Brazilian Portuguese in unmonitored conditions. The constituents that ought to be explicitly marked for plural (the noun menino 'boy' and the verb pega 'catches') are low saliency for the singular/plural opposition. Furthermore, subjects without a plural marker on the last element tend to trigger unmarked plural verbs. These

\footnotetext{
${ }^{1}$ SAINDO DA MATRIX. Available at:

http://www.saindodamatrix.com.br/archives/2011/05/cartilha_do_mec.html, Accessed January, 22, 2013.

${ }^{2}$ TERRA BRASILIS EDUCACIONAL. Available at:

http://profdiafonsoeducacion al.blogspot.com.br/2011/05/livro-usado-pelo-mec-ensina-aluno-falar.html. Accessed May, 30, 2012.

${ }^{3}$ See details and analysis in the site of Virgílio Almeida of the Universidade de Brasília. Available at: http://www.let.unb.br/lea/1/Virgilio/Bem-vindo.html. Then click on "NãoBlog" for the article o livro didático de língua portuguesa, updated FRIDAY, MAY 20, 2011. Accessed January, 20, 2013.

${ }^{4}$ The principal structural linguistic variables analyzed are: relative position in noun phrase, phrase level parallelism, and phonic salience for third person plural (Scherre and Naro 1991, 1992, 2010; Scherre 2001; Naro and Scherre 1996a); tense opposition and phonic salience for first person plural (Naro et alii 1999).
} 
effects have been described in detail in the relevant literature on Brazilian Portuguese for the last 30 years, in articles published in Language (Naro 1981), Language Variation and Change (Scherre and Naro 1991, 1992, Naro and Scherre 1996a, Scherre 2001) and in Selected Papers from NWAV 8 (Scherre 1981, Guy 1981), NWAV 23 (Naro and Scherre 1996b), NWAV 38 (Scherre and Naro $2010)^{5}$

The fact is that Ramos (2011) shows great linguistic sensitivity and presents structures that are genuinely natural in Brazilian Portuguese. Nonetheless, her examples triggered livid reactions from the most diverse users on the internet and other sectors of the community.

We turn now to objective sociolinguistic correlates to subjective negative evaluation. Specifically, we draw conclusions from the extreme polarization of VARBRUL relative weights associated with 'years of schooling' in a trend study of Rio de Janeiro speech from 1980 and 2000 (Paiva and Duarte 2003).

\section{Objective Sociolinguistic Correlates to Subjective Negative Evaluation}

Education is an important component of social class (Labov 2006), a concept difficult to measure objectively, especially in Brazilian society, where social frontiers are not so rigidly delimited. In Brazil, most researchers try to measure social class indirectly by using the number of years a speaker has spent in school. In this paper, we analyze the effect of years of schooling at two points in time.

Our data are taken from two random samples of the Rio de Janeiro community shown below.

(I) 1980 sample (Oliveira e Silva, and Scherre 1996:67-81): 64 hours recorded at the beginning of the 80 's with 64 speakers, stratified for:

a) gender, feminine and masculine;

b) years of schooling, subdivided into three levels of years of schooling in accord with the Brazilian school system: 1-4 years of school, 5-8 years of school, 9-11 years of school (the sample excludes speakers with more than 11 years of school - university level, as well as illiterate speakers);

c) age, subdivided into four levels: 07-14 years; 15-25 years; 26-49 years; more than 49 years.

(II) 2000 sample (Paiva and Duarte 2003:24-25): 32 hours recorded in 1999/2000 with 32 speakers from the same community as 1980 sample, with the same characteristics and subdivided in the same way.

The phenomena analyzed in these two samples involve use of variable third person plural forms similar to those cited in (1a) and (1c) from Ramos (2011:115). Thus, the theoretical examples in (4), (5) and (6) are typical of the real variable data we analyze for subject/verb concord (S/VC) and noun phrase concord (NPC):

Variable subject/verb concord (S/VC)

(4) Os menino(s) pega(m) o peixe 'the boys catches the fish'

Variable noun phrase concord (NPC)

(5) Os menino(s) pega o peixe 'the boy catches the fish'

(6) Os livro(s) ilustrado(s) mais interessante(s) estão emprestado 'the most interesting illustrated book are lent out'

For S/VC, we analyze 4,660 tokens from 1980 and 2,059 tokens from 2000 with $73 \%$ and $83 \%$ of concord, respectively. For NPC, we analyze 13,095 tokens from 1980 and 6,778 tokens from 2000 with $71 \%$ and $89 \%$ of concord, respectively. In terms of frequencies, we see an increase of 10 percentage points in S/VC and 18 percentage points in NPC, as shown in Table 1. Not including data at the far left of the noun phrase, in first position, which constitute about $40 \%$ of the total and exhibit almost $97 \%$ explicit plural marking, the increase in use of concord is about

\footnotetext{
5 See the many references in Scherre (2008).
} 
27 percentage points.

\begin{tabular}{|c|c|c|c|}
\hline Phenomena & Community 1980 & Community 2000 & $\begin{array}{l}\text { Overall } \\
\text { Increases }\end{array}$ \\
\hline \multicolumn{4}{|l|}{$\mathrm{S} / \mathrm{VC}$} \\
\hline Total & $3399 / 4660=73 \%$ & $1708 / 2059=83 \%$ & $\begin{array}{l}+10 \text { percentage } \\
\text { points }\end{array}$ \\
\hline \multicolumn{4}{|l|}{$\mathrm{NPC}$} \\
\hline $\begin{array}{l}\text { Total } \\
\text { (All data) }\end{array}$ & $9255 / 13095=71 \%$ & $6027 / 6778=89 \%$ & $\begin{array}{l}+18 \text { percentage } \\
\text { points }\end{array}$ \\
\hline $\begin{array}{l}\text { Total } \\
\text { (without non-head in } 1^{\text {st }} \\
\text { position) }\end{array}$ & $4375 / 8096=54 \%$ & $3093 / 3028=81 \%$ & $\begin{array}{l}+27 \\
\text { percentage points }\end{array}$ \\
\hline
\end{tabular}

Table 1: Overall use of marked forms for Subject/Verb Concord (S/VC) and Noun Phrase Concord (NPC) in 1980 and 2000 for two random samples of the community.

Results in terms of relative weights for all of the other variables with or without data from the first position in the noun phrase are very similar since relative position within the noun phrase, along with salience, is one of the most important variables. Relative weights, and differences between them, for NPC presented in 4.1 and 4.2, respectively, are derived from data including all nominal elements (including first position).

\subsection{On the Effect of Years of Schooling on Number Concord}

Close examination of relative weights generated by GoldVarb X, and their corresponding ranges (Tagliamonte 2006:242), reveals that the distance between the effects of each level of education has increased both for the community in general and in subgroups based on sex/gender for both types of concord (see Table 2, Figure 1a and Figure 1b).

\begin{tabular}{|l|l|l|l|l|l|l|}
\hline \multirow{2}{*}{ Years of schooling } & \multicolumn{2}{|c|}{ Community } & \multicolumn{2}{c|}{ Women only } & \multicolumn{2}{c|}{ Men only } \\
\cline { 2 - 7 } & 1980 & 2000 & 1980 & 2000 & 1980 & 2000 \\
\hline S/VC & & & & & & \\
\hline 1-4 years & .43 & .26 & {$[.46]$} & .22 & .42 & .29 \\
\hline 5-8 years & .55 & .50 & {$[.49]$} & .61 & .56 & .44 \\
\hline 9-11 years & .54 & .82 & {$[.56]$} & .83 & .51 & .81 \\
\hline Ranges & $\mathbf{1 2}$ & $\mathbf{5 6}$ & $\mathbf{1 0}$ & $\mathbf{6 1}$ & $\mathbf{1 4}$ & $\mathbf{5 2}$ \\
\hline NPC & & & & & & \\
\hline 1-4 years & .41 & .19 & .39 & .14 & .44 & .19 \\
\hline 5-8 years & .51 & .59 & .52 & .70 & .50 & .54 \\
\hline 9-11 years & .61 & .84 & .60 & .88 & .63 & .83 \\
\hline Ranges & $\mathbf{2 0}$ & $\mathbf{6 5}$ & $\mathbf{2 1}$ & $\mathbf{7 4}$ & $\mathbf{1 9}$ & $\mathbf{6 4}$ \\
\hline
\end{tabular}

Table 2: Relative weights for years of schooling for Subject/Verb Concord (S/VC) and Noun phrase concord (NPC) in 1980 and 2000 for two random samples of the community and subsamples according to sex/gender.

Polarization of the education variable in 1980 was moderate, with values around .40 for the lowest 1-4 year level and around .50/.60 for the highest 9-11 year level; in 2000 polarization becomes extreme, with values around .20 for the lowest level and around .80 for the highest level, in an increasingly uneven social distribution of marked forms. For subject/verb agreement, schooling was not selected as a statistically significant variable for women at either point in time. 


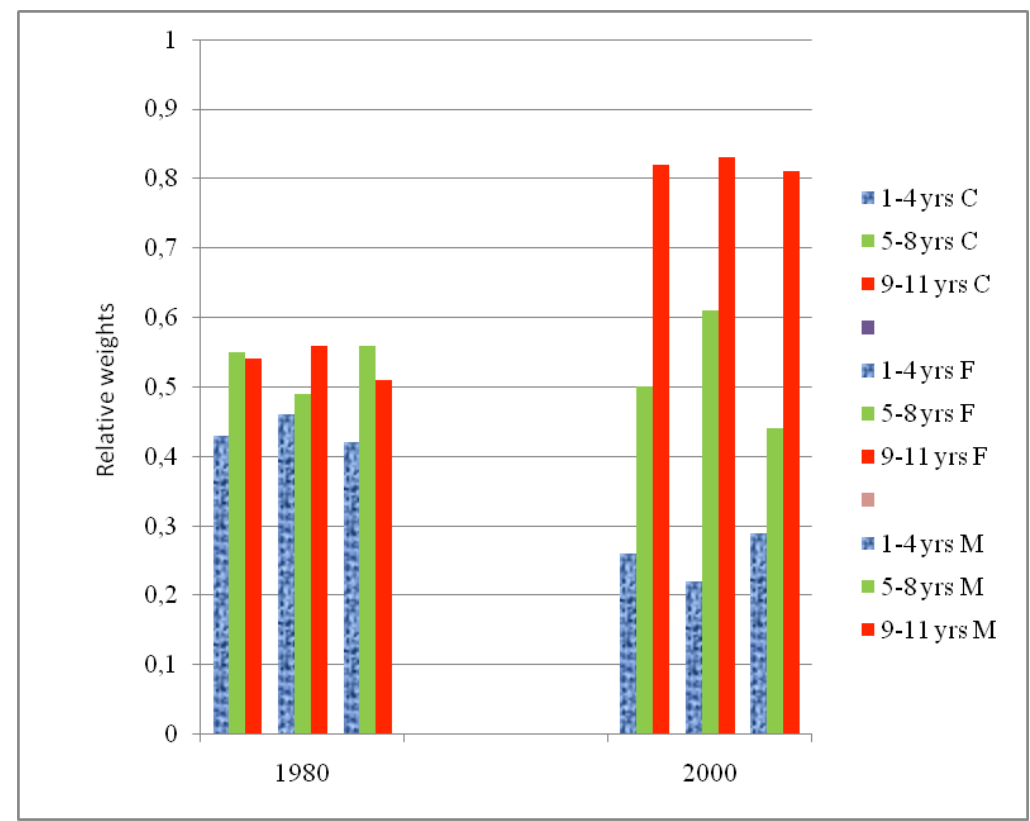

Figure 2a: Relative weights for years of schooling for Subject/Verb Concord (S/VC) in 1980 and 2000 for two random samples of the community $(\mathrm{C})$ and subsamples according to sex/gender (F and $\mathrm{M})$.

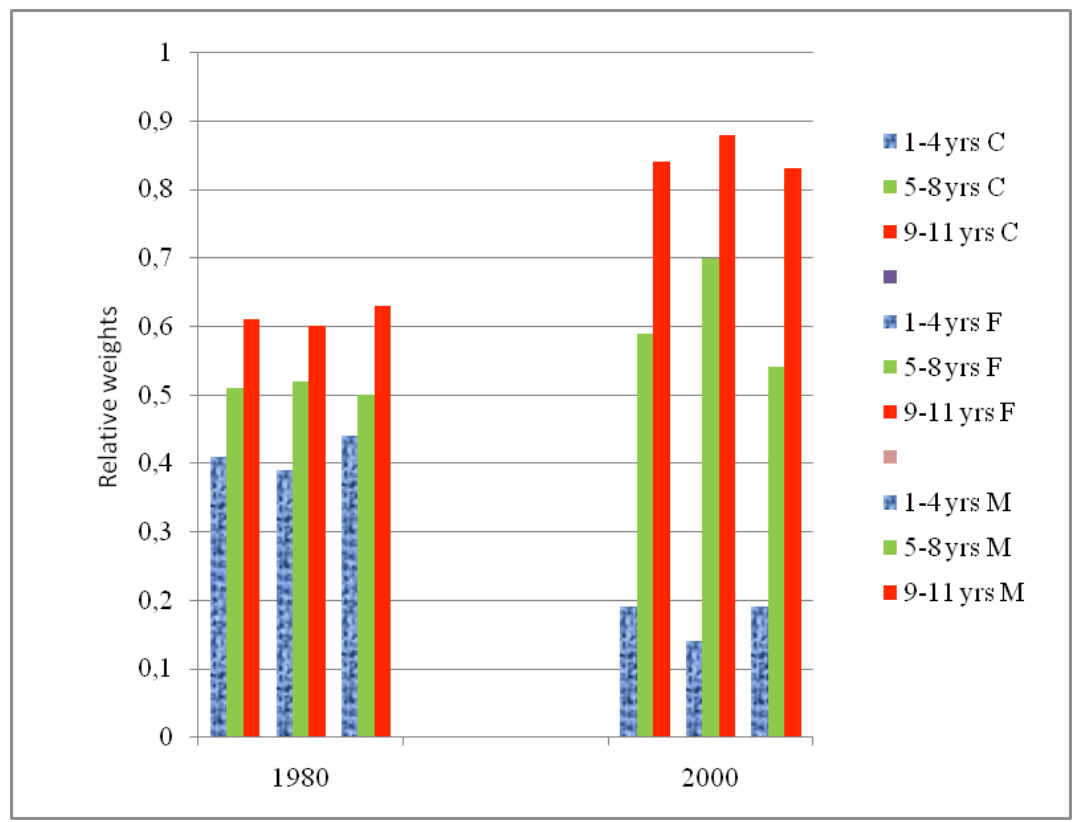

Figure 2b: Relative weights for years of schooling for Noun Phrase Concord (NPC) in 1980 and 2000 for two random samples of the community and subsamples according to sex/gender ( $\mathrm{F}$ and M).

The increased strength of the effect of schooling over the period between our two samples becomes clear when we compare the ranking of variables in terms of magnitude of internal ranges across variables. For the community as a whole in 1980, in the case of subject verb concord, the magnitude of the range associated with Schooling comes in at 11th place among the ranges associated with 12 selected variables at 12; in 2000, it reaches 1st place among the ranges of 11 
selected variables, with the greatest range at 56. In the case of noun phrase concord, in 1980 the range of schooling comes in at 6th place among 6 selected variables, at 20; in 2000, it reaches second position among 7 selected variables, with the second greatest range at 65 .

Exactly the same phenomenon is found for the sub-universes consisting of male and female speakers. $^{6}$

For subject/verb concord in men in 1980, schooling exhibits a range of 14, the lowest range of all, in a set of eight selected variables. In 2000, on the other hand, schooling shows the highest range, at around 52, in a set of six selected variables. For noun phrase concord among men, range of schooling comes in at fifth place in 1980, (together with age group, with a range of 19), in a set of seven selected variables. In 2000, schooling has the second largest range (64), in a set of six selected variables.

In the case of subject/verb concord for women in 1980, schooling was not even selected as statistically significant, but in 2000, it was not only selected in first place, it also shows the greatest range (61) in a set of ten selected variables. For noun phrase concord in 1980, schooling exhibits the second smallest range at 21 , in a set of seven selected variables, but in 2000 , schooling exhibits the second highest range (74) of five selected variables.

\subsection{On the Effect of Years of Schooling and Media on Number Concord}

The point we are emphasizing in this paper is the increased strength of the effect of formal schooling on the acquisition of standard forms of concord in the period under study. But contact with media is another source of experience with standard forms, especially relevant for less privileged people who have little effective contact in real life with speakers with high rates of usage of standard forms. In fact, the very first study of concord in Rio was carried out in the early 80 's with functionally illiterate speakers who had little or no contact with either the school system or with standard language speakers in their daily activities (Naro 1981). Yet some of these speakers showed exceptionally high rates of standard concord forms, rivaling or exceeding middle class rates. It was shown in the early work that there was a tight correlation for these illiterate speakers between standard usage and contact with mass media, especially television soap operas. For these people, media seemed to be providing a vicarious path into the life experience of more privileged social classes that was unavailable to them in real life. For them, an indirect connection via media showed itself to be more viable than direct instruction in school as way to achieve contact with standard forms. It was more open, more accessible for those motivated to penetrate socially prestigious forms of behavior.

Our results show that media is losing its effectiveness in comparison to schooling. In the Table 3 we can see that ranges for schooling increase and those for media decrease for both concord phenomena between 1980 and 2000, for the community as a whole as well as for women. The only exception is for the subgroup of male speakers, for whom schooling assumed a marginally leading role already in the early period, continuing in this leading role with more polarization in the second period. In 2000, media increases in polarization, but schooling increases more strongly.

\begin{tabular}{|l|l|l|l|}
\hline $\begin{array}{l}\text { Samples and } \\
\text { Subsamples }\end{array}$ & $\begin{array}{l}\text { Independent } \\
\text { variables }\end{array}$ & $\begin{array}{l}\text { Subject/verb } \\
\text { concord }\end{array}$ & $\begin{array}{l}\text { Noun Phrase } \\
\text { Concord }\end{array}$ \\
\hline Community & & & \\
\hline 1980 & Media & 26 & 38 \\
\hline & Schooling & 12 & 20 \\
\hline 2000 & Media & 15 & 07 \\
\hline
\end{tabular}

\footnotetext{
${ }^{6}$ The role of media in the two concord phenomena examined here can be seen in Naro and Scherre (1996b). Furthermore, the specific role of women in S/VC with respect to age can be seen in Scherre and Naro (2010). Given this background, we decided to study the role of schooling separately according to sex/gender. We should add that we are using the term 'sex/gender' because our coding was made on the basis of biological sex, while discussions of this variable tend to be in terms of gender.
} 


\begin{tabular}{|l|l|l|l|}
\hline & Schooling & 56 & 65 \\
\hline Women only & & & \\
\hline 1980 & Media & 33 & 38 \\
\hline & Schooling & {$[10]$} & 21 \\
\hline 2000 & Media & {$[09]$} & {$[06]$} \\
\hline & Schooling & 61 & 74 \\
\hline Men only & & & \\
\hline 1980 & Media & {$[01]$} & 16 \\
\hline & Schooling & 14 & 19 \\
\hline 2000 & Media & 34 & 12 \\
\hline & Schooling & 52 & 64 \\
\hline
\end{tabular}

Table 3: Competition among the effect of years of schooling and media on concord in 1980 and 2000 in terms of ranges for the community and for sex/gender subsamples.

\section{Reflections}

Our results show that education has a much stronger statistical effect on use of standard concord in Rio de Janeiro in 2000 than it did in 1980. The meaning of our results in the real world is, however, in need of closer examination. What we have studied is the strength of the correlation between level of education and use of standard forms, not its cause.

One possible interpretation is that education has been improving and becoming more effective over the years. Students now appear to benefit more from their years spent at school than they used to in relation the use of standard concord. But at least in principle another interpretation is possible: perhaps students who are unable to absorb the standard are now more effectively excluded or expelled from the school system as the years progress, creating the illusion that schools are working more efficiently. We feel that this second line of interpretation is unlikely because enrollment at school is increasing, not decreasing, and with the creation of new full time schools known as Centros Integrados de Educação Pública during the governorship of Leonel Brizola in the 80's and 90's students can now spend more time each day at school.

In the present paper we have shown that the statistical effect of schooling is stronger now than twenty years ago, especially in our group with 9 to 11 years of school. Coincidentally, or not, it is in this particular group that there has been the greatest increase of attendance in the school system between the censuses of 1980 and 2000. The group with 1-3 years of school remained stable at more or less $20 \%$ of the population, while $4-7$ years remained at the $25 \%$ level. 8-10 years of school, however, increased from 7 to $13 \%$ and $11-14$ years from $5 \%$ to $14 \%$. These two census groups cover the 9-11 group of the present paper.

However this may be, the fact of the matter is that formal education is creating more profound linguistic divisions in society than before, setting up a sort of social apartheid for those members of the Rio community who for one reason or another evade the school system. In other words, whether due to increased efficiency of teaching, or increased evasion, speakers with higher levels of education now appropriate a greater proportion of the linguistic standard than those with less education. Education is creating more inequality in the community than it used to.

It is important to emphasize that in terms of raw frequencies, all of the speakers recorded in 2000 increased their level of use of concord. Differences between effects of schooling in the two samples appear exasperated in terms of relative weights, calculated as differences in relation to the mean (or input) as well as by taking into consideration the effect of other variables, including sex/gender and media. These variables show partially different behavior in the two samples, as we have already seen. Even so, in the very first level of the relative weight calculation, the ranges of the 2000 sample are much larger than those of the 1980 sample for both phenomena, as can be seen in Table 4. The fact is that speakers with 9-11 years of schooling in the urban area of Rio de Janeiro in our 2000 sample show frequencies of concord on the order of $95 \%$ for subject/verb concord and around $98 \%$ for noun phrase concord, taking into account the entire noun phrase or $96 \%$ if the first (or left-most) nominal position is eliminated. For these speakers, in the situation of 
a sociolinguistic interview (Labov 1975:79-80; 85-99), concord is semi-categorical, in Labov's (2003:241-243) terminology. ${ }^{7}$

\begin{tabular}{|c|c|c|c|c|c|c|}
\hline \multirow[b]{2}{*}{$\begin{array}{l}\text { Years of } \\
\text { schooling }\end{array}$} & \multicolumn{3}{|c|}{ Community 1980} & \multicolumn{3}{|c|}{ Community 2000} \\
\hline & Frequency & $\begin{array}{l}\text { Relative } \\
\text { weight } \\
\text { level } 1\end{array}$ & $\begin{array}{l}\text { Relative } \\
\text { weight } \\
\text { level } 12\end{array}$ & Frequency & $\begin{array}{l}\text { Relative } \\
\text { weight } \\
\text { level } 1\end{array}$ & $\begin{array}{l}\text { Relative } \\
\text { weight } \\
\text { level } 11\end{array}$ \\
\hline \multicolumn{7}{|l|}{$\mathrm{S} / \mathrm{VC}$} \\
\hline $1-4$ years & $1128 / 1794=63 \%$ & .38 & .43 & $561 / 719=72 \%$ & .30 & .26 \\
\hline $5-8$ years & $1378 / 1770=78 \%$ & .56 & .55 & $726 / 851=85 \%$ & .50 & .50 \\
\hline 9-11 years & $893 / 1096=82 \%$ & .61 & .54 & $466 / 489=95 \%$ & .78 & .82 \\
\hline Total & $3390 / 4660=73 \%$ & & & $1708 / 2059=83 \%$ & & \\
\hline Input & & .73 & .82 & & .83 & .93 \\
\hline Ranges & & 23 & 12 & & 48 & 56 \\
\hline $\begin{array}{l}\text { NPC } \\
\text { (All data) }\end{array}$ & Frequency & $\begin{array}{l}\text { Relative } \\
\text { weight } \\
\text { level } 1\end{array}$ & $\begin{array}{l}\text { Relative } \\
\text { weight } \\
\text { level } 12\end{array}$ & Frequency & $\begin{array}{l}\text { Relative } \\
\text { weight } \\
\text { level } 1\end{array}$ & $\begin{array}{l}\text { Relative } \\
\text { weight } \\
\text { level } 12\end{array}$ \\
\hline $1-4$ years & $2966 / 4800=62 \%$ & .39 & .41 & $1909 / 2434=78 \%$ & .25 & .19 \\
\hline $5-8$ years & $3449 / 4843=71 \%$ & .50 & .51 & $2588 / 2777=93 \%$ & .56 & .59 \\
\hline 9-11 years & $2840 / 3452=82 \%$ & .65 & .61 & $1530 / 1567=98 \%$ & .79 & .84 \\
\hline Total & $9255 / 13095=71 \%$ & & & $6027 / 6778=89 \%$ & & \\
\hline Input & & .71 & .83 & & .89 & .98 \\
\hline Ranges & & .26 & 20 & & 54 & 65 \\
\hline $\begin{array}{l}\text { NPC } \\
\text { (Without } \\
\text { non-head } \\
\text { in } 1^{\text {st }} \\
\text { position) }\end{array}$ & Frequency & $\begin{array}{l}\text { Relative } \\
\text { weight } \\
\text { level } 1\end{array}$ & $\begin{array}{l}\text { Relative } \\
\text { weight } \\
\text { level } 8\end{array}$ & Frequency & $\begin{array}{l}\text { Relative } \\
\text { weight } \\
\text { level } 1\end{array}$ & $\begin{array}{l}\text { Relative } \\
\text { weight } \\
\text { level } 7\end{array}$ \\
\hline $1-4$ years & $1145 / 2930=39 \%$ & .35 & .41 & $816 / 1336=61 \%$ & .21 & .17 \\
\hline $5-8$ years & $1674 / 3025=55 \%$ & .51 & .51 & $1407 / 1586=89 \%$ & .57 & .59 \\
\hline 9-11 years & $1556 / 2141=73 \%$ & .69 & .61 & $870 / 906=96 \%$ & .81 & .84 \\
\hline Total & $4375 / 8096=54 \%$ & & & $3093 / 3828=81 \%$ & & \\
\hline Input & & .54 & .57 & & .81 & .90 \\
\hline Ranges & & 34 & 20 & & .60 & 67 \\
\hline
\end{tabular}

Table 4: Frequencies and relative weights for years of schooling for Subject/Verb Concord (S/VC) and Noun Phrase Concord (NPC) in 1980 and 2000: two random samples of the community.

The case of true casual speech has not yet been studied to a great extent in Brazilian Portuguese, but there are strong indications that under more natural conditions, even speakers with more than 11 years of schooling, tend to vary between $24 \%$ and $98 \%$ for subject $/ v e r b$ and $46 \%$ to $90 \%$ for noun phrase concord, depending on interlocutor (Pereira and Scherre 1995). ${ }^{8}$

Returning to our main point, we wish to emphasize once again that Ramos (2011) shows great linguistic sensitivity and presents structures that are genuinely natural in Brazilian Portuguese. Nonetheless, her examples triggered livid reactions from the most diverse users on the internet and other sectors of the community. Anyone with a wider or more democratic view of the phenomenon of language, even if a layman, would find it hard to even take seriously such irate

\footnotetext{
${ }^{7}$ The data analyzed here are drawn from the entire interview, without distinguishing between Careful Speech (Style B) and Casual speech (Style A) in the terminology of Labov (2003:96).

${ }^{8}$ These results come from an undergraduate level study of a male upper middle class speaker with more than 11 years of schooling. This speaker holds a Masters degree in artificial insemination and is a farm administrator. He was recorded in three different interactional situations: talking to the farm workers, talking to his wife, and talking to his boss.
} 
proclamations.

Of course, the strong reactions of life-long teachers of "how to speak and write correctly" can be considered only natural, given the effort expended over the years, but for the sake of the common good, it is urgent that linguistic prejudice be publicly debated in the same way as society now discusses, and sets legal consequences, for prejudice with respect to sexual orientation, ethnicity, gender, religion, poverty, and lower class professions. People in the days of slavery, for example, could hardly have imagined that today descendants of these same slaves would possess the right to recourse to the courts against anyone who exhibits racial or other prejudice against them.

There was negative reaction to the textbook even on the legal level. Nascimento (2012:10), a journalist writing in Revista Via Legal, published by the Federal Department of Justice, reports that "the supposed errors caused a polemic and motivated a group of lawyers to bring a court case with the aim of blocking further use of the book." For reasons independent of the actual linguistic structures cited in the textbook, according to Nascimento (2012:10), at the end of 2011 a judge on the 13th Federal Circuit of São Paulo "decided in a preliminary injunction that interruption of the use of the textbook would not be a solution since the students were about to complete the school year." 10

The results reveal massive exacerbation of sociolinguistic apartheid, the basis for overwhelmingly negative public opinion of the textbook mentioned at the outset. Here we see clear objective sociolinguistic correlates to the subjective reactions to the textbook we have mentioned.

Apparently, many years of language studies show that nothing has changed in human interaction with respect to language. Therefore, we suggest that our sociolinguistic studies ought to trigger legal action, with creation of laws against linguistic prejudice, modeled on laws against other forms of prejudice, so that society can profit from results of sociolinguistic research in a humanistic and emancipatory way (Sankoff 1988; Scherre 2008).

As Sankoff (1988:144) emphasize "it is in engaging in this conflict of ideologies that linguistics may have a socially emancipatory role."

\section{References}

Bagno, Marcos. 2011. A língua, a mídia e a ordem do discurso. Ms., Universidade de Brasília.

Bortoni- Ricardo, Stella Maris Paula Cobucci and Virgilio Almeida. 2011. Introducing sociolinguistics in the Portuguese language syllabus of Brazilian schools. Paper presented at NWAV 40, Georgetown

Guy, Gregory. 1981. Parallel Variability in American dialects of Spanish and Portuguese. In Variation Omnibus, ed. David Sankoff and Henrietta Cedergren, 85-93. Canada, Linguistic Research, Inc.

Labov, William. 1975. Sociolinguistics Patterns. Philadelphia: University of Pennsylvania Press.

Labov, William. 2003 [1969]. Some Sociolinguistic Principles. In Sociolinguistics - The Essential Readings, ed. Christina Bratt Paulston, and G. Richard Tucker, 234-250. Oxford/New York: Blackwell.

Labov, William. 2006. The Social Stratification of English in New York City. New York: Cambridge University Press.

Nascimento, Bianca. 2012. O “errado” pode ser certo. In: Revista Via Legal, Ano V, n. XIII - jan./abr. 10-11. Brasília: Centro de Produções da Justiça Federal.

Naro, Anthony Julius. 1981. The social and structural dimensions of a syntactic change. Language 57(1): 6398.

Naro, Anthony Julius, Edair Gorski and Eulália Fernandes. 1999. Change without change. Language variation and change 11:197-211.

Naro, Anthony Julius and Maria Marta Pereira Scherre,. 1996a, Disfluencies in the analysis of speech data. Language variation and change 8:1-12.

\footnotetext{
${ }^{9}$ In the original: "Os supostos erros gramaticais foram alvo de polêmica e motivaram um grupo de advogados a mover ação popular com o objetivo de interromper o uso do livro didático." (Nascimento 2012:10)

${ }^{10}$ In the original: "No fim de 2011, o magistrado decidiu liminarmente que a suspensão do uso do material didático não seria a solução, pois os alunos já estavam perto de concluir o ano letivo." (Nascimento 2012:10)
} 
Naro, Anthony Julius and Maria Marta Pereira Scherre. 1996b. Contact with Media and Linguistic Variation In Sociolinguistic Variation - Data, Theory, and Analysis: Selected Papers from NWAV 23 at Stanford, ed. Stanford, California: SSCL (Center for the study of language and information) Publications, 223228.

Naro, Anthony Julius, and Maria Marta Pereira Scherre. 2013. Remodeling the age variable: number concord in Brazilian Portuguese. Language Variation and Change 25:1-15.

Oliveira e Silva, G. M. de and Maria Marta Pereira Scherre. 1996. eds. Padrões sociolinguísticos: análise de fenômenos variáveis do português falado na cidade do Rio de Janeiro. Rio de Janeiro: Tempo Brasileiro.

Paiva, Maria da Conceição de and Maria Eugênia Lamoglia Duarte. 2003. Rio de Janeiro: Contra Capa e FAPERJ.

Pereira, Andréa Kluge and Maria Marta Pereira Scherre. 1995. A influência do contexto interacional na concordância de número no português do Brasil. Paper presented at II Congresso de Ciências Humanas, Letras e Artes das IFES mineiras, Universidade Federal de Uberlândia.

Ramos, Heloísa. 2011. Por uma vida melho. São Paulo: Ação Educativa Global. 11-27.

Sankoff, David. 1988. Sociolinguistics and Syntactic Variation. In Linguistics: the Cambridge survey IV: Language: the socio-cultural context, ed. Frederick J. Newmeyer, 141-160. New York: Cambridge University Press.

Scherre, Maria Marta Pereira. 1981. Variation de la regle d'accord du nombre dans le syntagme nominal en Portugais. In Variation Omnibus, ed. David Sankoff and Henrietta Cedergren, 125133. Canada, Linguistic Research, Inc.

Scherre, Maria Marta Pereira. 2001. Phrase level parallelism effect on noun phrase number agreement. Language Variation and Change 3, 91-107.

Scherre, Maria Marta Pereira. 2008. Doa-se lindos filhotes de poodle - variação linguistica, mídia e preconceito. São Paulo: Parábola.

Scherre, Maria Marta Pereira and Anthony Julius Naro. 1991. Marking in Discourse: Birds of a Feather. Language Variation and Change 3:23-32.

Scherre, Maria Marta Pereira and Anthony Julius Naro. 1992. The serial effect on internal and external variables. Language Variation and Change 4:1-13.

Scherre, Maria Marta Pereira and Anthony Julius Naro. 2010. Perceptual vs. grammatical constraints and social factors in subject-verb agreement in Brazilian Portuguese. In U. Penn Working Papers in Linguistics 16.2: Selected Papers from NWAV 38, 165-171.

Tagliamonte, Sali. A. 2006. Analyzing sociolinguistic variation. Cambridge: University Cambridge Press.

Departamento de Linguística, Português e Línguas Clássicas

Universidade de Brasília

Brasília, CEP 79910-900

mscherre@terra.com.br or mscherre@gmail.com

Departamento de Linguística e Filologia

Universidade Federal do Rio de Janeiro

Rio de Janeiro, CEP 21941-590

anaro@gmx.net 